\title{
Syntheses of Bufotoxin Analogs ${ }^{1)}$
}

\author{
Kazutake Shimada, Youichi Fujil, and Toshio Nambara \\ Pharmaceutical Institute, Tohoku University2)
}

(Received January 31, 1973)

\begin{abstract}
In order to examine the physiological activity the arginine-linked cardiotonic steroids have been synthesized as bufotoxin analogs. Resibufogenin 3-suberoyl-p-nitrophenyl ester, derivable from the 3 -suberate, was condensed with $\mathrm{L}$-arginine hydrochloride to yield resibufogenin 3-suberoyl-L-arginine. In an analogous manner digitoxigenin 3-suberate was converted into 3-suberoyl-L-arginine, -L-arginyl-L-arginine and -L-arginyl-L-proline via the activated $p$-nitrophenyl ester. The structure of the product was verified by leading to the pyrimidine derivative, respectively.
\end{abstract}

The so-called "bufotoxin" which was isolated from the toad venom by Wieland, et al.,"3) has recently been characterized as bufogenin 3 -suberoylarginine by the degradative means.4) It has been suggested that the genuine steroid toad venom may be a peptide conjugate linked with L-arginyl-L-arginyl-L-proline. ${ }^{5)}$ The presence of physiologically active peptides in the skin of amphibian animals ${ }^{6}$ also implies the possible occurrence of the steroidal peptide containing a segment of kinin as toad venom constituent. In addition the discovery of the cardenolide and its 3-suberate in the Chinese drug, $\mathrm{Ch}^{\prime}$ an $\mathrm{Su},{ }^{7}$ indicates that the analogous conjugated cardenolide may occur as the natural product. In these respects the physiological activity of the arginine-linked steroidal peptide appears to be of particular interest. The present paper deals with the syntheses of resibufogenin 3-suberoyl-L-arginine and digitoxigenin 3-suberoyl-L-arginine, -L-arginyl-L-arginine and -L-arginyl-L-proline.

In the previous work of this series we developed a synthetic route to digitoxigenin 3-suberoylamino acid from its 3 -suberate via the activated $p$-nitrophenyl ester. ${ }^{8)}$ It is substantiated that condensation reaction of the $p$-nitrophenyl ester with arginine hydrogen halide takes place preferentially at the $\alpha$-amino group rather than the guanidino residue. ${ }^{9)}$ The $p$-nitrophenyl ester method, therefore, appeared to be promising for preparation of the desired compounds. When digitoxigenin 3-suberoyl-p-nitrophenyl ester (Ib), derivable from the 3-suberate (Ia), was stirred with L-arginine hydrochloride in aqueous pyridine at room temperature, facile condensation was effected. Subsequent purification by column chromatography on silica gel provided digitoxigenin 3-suberoyl-L-arginine hydrochloride (Ic). This substance gave the positive result with the Sakaguchi's reagent and the negative test with

1) This paper constitutes Part XV of the series entitled "Studies on Cardiotonic Steroid Analogs"; Part XIV: K. Shimada, Y. Fujii, and T. Nambara, Chem. Pharm. Bull. (Tokyo), 21, 1031 (1973). A part of this work has been presented as a preliminary account: K. Shimada, Y. Fujii, and T. Nambara, Chem. Ind. (London), 1972, 258.

2) Location: Aobayama, Sendai.

3) H. Wieland and R. Alles, Ber., 55, 1789 (1922); H. Wieland, G. Hesse, and R. Hüttel, Ann., 524, 203 (1936) ; H. Wieland and H. Behringer, ibid., 549, 209 (1941).

4) H.O. Linde-Tempel, Helv. Chim. Acta, 53, 2188 (1970).

5) G.R. Pettit, R.L. Smith, and H. Klinger, J. Med. Chem., 10, 145 (1967).

6) V. Erspamer and A. Anastasi, "Hypotensive Peptides," ed. by E.G. Erdös, N. Back, and F. Sicuteri, Springer-Verlag, Inc., New York, 1966, pp. 63-75.

7) N. Höriger, H.H.A. Linde, and K. Meyer, Helv. Chim. Acta, 53, 1503 (1970); N. Höriger, C. Zivanov, H.H.A. Linde, and K. Meyer, ibid., 53, 1993 (1970); idem, ibid., 53, 2051 (1970).

6) K. Shimada and T. Nambara, Chem. Pharm. Bull. (Tokyo), 19, 1073 (1971); T. Nambara, K. Shimada, and Y. Fujii, Chem. Pharm. Bull. (Tokyo), 20, 1424 (1972).

9) E. Wünsch, G. Wendlberger, and A. Högel, Chem. Ber., 104, 2430 (1971). 
ninhydrin, which indicated the formation of a peptide bond involving the $\alpha$-amino group of arginine. In order to confirm this point Ic was further converted into the pyrimidine derivative (If) by treatment with acetylacetone-potassium hydrogen carbonate and then with diazomethane. Unfortunately the reaction product could not be obtained in the crystalline state, but the structure was unequivocally assignable from the nuclear magnetic resonance (NMR) and ultraviolet (UV) spectral data.

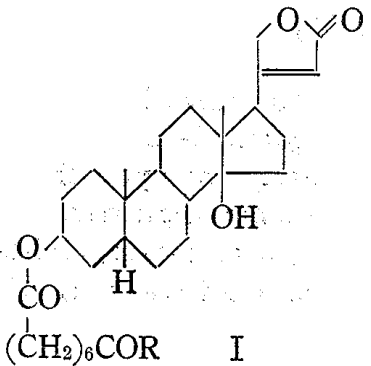

$\mathrm{a}: \mathrm{R}=\mathrm{OH}$<smiles>[R]Oc1ccc([N+](=O)[O-])cc1</smiles>

$\mathrm{NH}$

d : $\mathrm{R}=\mathrm{NHCH}\left(\mathrm{CH}_{2}\right)_{3} \mathrm{NHCNH}_{2} \cdot 2 \mathrm{ACOH}$ $\mathrm{CONHCH}\left(\mathrm{CH}_{2}\right)_{3} \mathrm{NHCNH}_{2}$ $\mathrm{COOH} N \mathrm{NH}$<smiles></smiles>

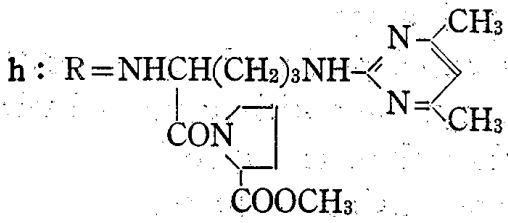<smiles>CC(=O)OC1CCCC2C1CCCC1C2CCC2(c3ccc(O)cc3)CCOC12</smiles>

$\mathrm{NH}$<smiles></smiles>
$\mathrm{COOH}$<smiles>[R]N=CCCCCCC(=N)NCC(=O)O</smiles>

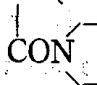<smiles>O=C(O)CCCCCCCC(=O)O</smiles>

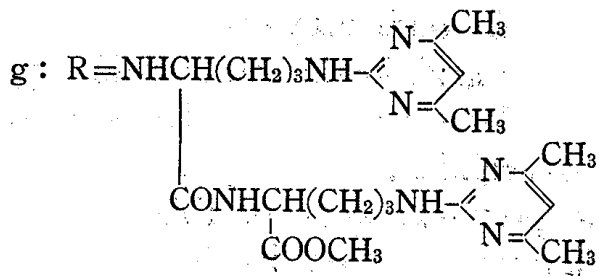

Chart 1

In a similar fashion the synthesis of resibufogenin 3-suberoyl-L-arginine was then undertaken. ${ }^{10)}$ Being treated with $p$-nitrophenol in the presence of $\mathrm{N}, \mathrm{N}^{\prime}$-dicyclohexylcarbodiimide, resibufogenin 3-suberate (IIa) ${ }^{12}$ ) was readily transformed into the $p$-nitrophenyl ester (IIb). Condensation of IIb with L-arginine hydrochloride followed by chromatographic purification on silica gel afforded the desired resibufogenin 3-suberoyl-L-arginine hydrochloride (IIc) in a satisfactory yield.

The next project was directed to the preparation of digitoxigenin 3-suberoylpeptides containing arginine-linked peptide. Condensation of $\mathrm{Ib}$ with L-arginyl-L-arginine diacetate in aqueous pyridine was effected by stirring at room temperature. Subsequent purification by chromatography on silica gel followed by gel filtration on Sephadex LH-20 provided the desired 3-suberoyl-L-arginyl-L-arginine derivative (Id)... In an analogous series of experiments, digitoxigenin 3-suberoyl-L-arginyl-L-proline acetate (Ie) was prepared from $\mathrm{Ib}$ by direct condensation with L-arginyl-L-proline acetate. Similarly the formation of the pyrimidine

10) Independently Pettit, et al. have presented a paper dealing with the syntheses of 3-suberoylarginine esters of resibufogenin, bufotalin, and bufalin by the mixed anhydride method. ${ }^{11)}$

11) G.R. Pettit and Y. Kamano, Chem. Commun., 1972, 45.

12) Y. Kamano, H. Yamamoto, $Y$. Tanaka, and M. Komatsu, Tetrahedron Letters, 1968, 5673. 
derivatives $(\mathrm{Ig}, \mathrm{Ih})$ by treatment with acetylacetone and then with diazomethane verified the assigned structures of these peptide conjugates.

The availability of the arginine-linked steroidal peptides related to bufotoxin should serve as a useful reference compound for study of the toad venom constituents. The results of the pharmacological test will be reported elsewhere in the near future.

\section{Experimental ${ }^{13)}$}

Digitoxigenin 3-Suberoyl-L-arginine Hydrochloride (Ic) - To a solution of digitoxigenin 3-suberoyl-pnitrophenyl ester $(\mathrm{Ib})^{8)}(40 \mathrm{mg})$ in pyridine $(2 \mathrm{ml})$ was added an aq. solution of L-arginine. $\mathrm{HCl}(15 \mathrm{mg} \mathrm{in} 1 \mathrm{ml}$ ), and allowed to stand at room temperature for $16 \mathrm{hr}$. The resulting solution was concentrated in vacuo and the residue obtained was chromatographed on silica gel $(500 \mathrm{mg})$. Elution with AcOEt-MeOH (4:1) and recrystallization of the eluate from $\mathrm{MeOH}$-acetone gave Ic $(15 \mathrm{mg})$ as colorless amorphous substance. $\mathrm{mp} 109-111^{\circ} .[\alpha]_{\mathrm{D}}^{17}+15.0^{\circ}(c=0.10, \mathrm{MeOH})$. Anal. Calcd. for $\mathrm{C}_{37} \mathrm{H}_{58} \mathrm{O}_{8} \mathrm{~N}_{4} \cdot \mathrm{HCl} \cdot 2 \mathrm{H}_{2} \mathrm{O}, \mathrm{C}, 58.52, \mathrm{H}$, 8.36; N, 7.38. Found: C, 58.42; H, 8.27; N, 7.19. IR $\nu_{\max }^{\mathrm{KBr}} \mathrm{cm}^{-1}: 3280(\mathrm{OH}, \mathrm{NH}), 1730(\mathrm{C}=\mathrm{O}), 1665,1625$ (monosubstituted guanidine $\mathrm{C}=\mathrm{N}$ ).

Transformation of Ic into Pyrimidine Derivative (If) — A solution of Ic $(50 \mathrm{mg})$ in acetylacetone- $\mathrm{KH}$ $\left.\mathrm{CO}_{3}^{4}\right) \cdot(3 \mathrm{ml})$ was allowed to stand at $40^{\circ}$ for $16 \mathrm{hr}$. The resulting solution was extracted with $\mathrm{CHCl}_{3}$, and the organic layer was separated and concentrated in vacuo. The residue obtained was dissolved in $\mathrm{MeOH}$ $(1 \mathrm{ml})$ and treated with an ethereal solution of $\mathrm{CH}_{2} \mathrm{~N}_{2}$ in the usual manner. The crude product was submitted to the preparative thin-layer chromatography (TLC) using AcOEt as developing solvent. The adsorbent corresponding to the spot $(R f 0.70)$ was eluted with AcOEt. Unfortunately the eluate (15 mg) could not be crystallized, but it was substantially homogeneous according to TLC. UV $\lambda_{\max }^{\mathrm{E} \text { tor }} \mathrm{nm}-217,239$, 303. NMR ( $4 \%$ solution in $\left.\mathrm{CDCl}_{3}\right) \delta: 0.88\left(3 \mathrm{H}, \mathrm{s}, 18-\mathrm{CH}_{3}\right), 0.97\left(3 \mathrm{H}, \mathrm{s}, 19-\mathrm{CH}_{3}\right), 2.30(6 \mathrm{H}, \mathrm{s}$, pyrimidine4,6- $\left.\mathrm{CH}_{3}\right), 3.73\left(3 \mathrm{H}, \mathrm{s},-\mathrm{COOCH}_{3}\right), 4.90\left(2 \mathrm{H}, \mathrm{m}, 21-\mathrm{CH}_{2}\right), 5.10(1 \mathrm{H}, \mathrm{m}, 3 \alpha-\mathrm{H}), 5.50(1 \mathrm{H}, \mathrm{m},-\mathrm{NH}$-pyrimidine $)$, $5.90(1 \mathrm{H}, \mathrm{m}, 22-\mathrm{H}), 6.31(1 \mathrm{H}, \mathrm{s}$,pyrimidine-5-H), $6.45(1 \mathrm{H}, \mathrm{m}, \mathrm{CONH}-)$.

Resibufogenin 3-Suberoyl-p-nitrophenyl Ester (IIb)-To a solution of resibufogenin 3-suberate (IIa) in) $^{\text {2) }}$ $(50 \mathrm{mg})$ and $p$-nitrophenol $(20 \mathrm{mg})$ in AcOEt was added $\mathrm{N}, \mathrm{N}^{\prime}$-dicyclohexylcarbodimide $(10 \mathrm{mg})$ under ice-cooling and allowed to stand at room temperature for $16 \mathrm{hr}$. The precipitated dicyclohexylurea was filtered off and washed with AcOEt. The filtrate and washings were combined and concentrated in vacuo. The crude product was submitted to the preparative TLC using benzene-AcOEt $(4: 1)$ as developing solvent. The adsorbent corresponding to the spot $(R f 0.54)$ was eluted with AcOEt, and recrystallization of the eluate from acetone-MeOH gave IIb $(30 \mathrm{mg})$ as colorless prisms. mp 97-98. $\quad[\alpha]_{0}^{17}+6.3^{\circ}\left(c=0.16, \mathrm{CHCl}_{3}\right)$. Anal. Calcd. for $\mathrm{C}_{38} \mathrm{H}_{47} \mathrm{O}_{9} \mathrm{~N}: \mathrm{C}, 68.96 ; \mathrm{H}, 7.16 ; \mathrm{N}, 2.12$. Found $\mathrm{C}, 68.63 ; \mathrm{H}, 7.34 ; \mathrm{N}, 2.18$. NMR $(4 \%$ solution in $\left.\mathrm{CDCl}_{3}\right) \delta: 0.78\left(3 \mathrm{H}, \mathrm{s}, 18-\mathrm{CH}_{3}\right), 0.99\left(3 \mathrm{H}, \mathrm{s}, 19 \mathrm{CH}_{3}\right), 3.57 .(1 \mathrm{H}, \mathrm{s}, 15 \alpha-\mathrm{H}), 5.10(1 \mathrm{H}, \mathrm{m}, 3 \alpha-\mathrm{H}), 6.23(1 \mathrm{H}$, $\mathrm{d}, J=10 \mathrm{~Hz}, 23-\mathrm{H}), 7.25(1 \mathrm{H}, \mathrm{d}, J=2 \mathrm{~Hz}, 21-\mathrm{H}), 7.30\left(2 \mathrm{H}, \mathrm{d}, J=10 \mathrm{~Hz},-\left\langle=>-\mathrm{NO}_{2}\right), 7.80(1 \mathrm{H}, \mathrm{q}, J=\right.$ $10,2 \mathrm{~Hz}, 22-\mathrm{H}), 8.25\left(2 \mathrm{H}, \mathrm{d}, J=10 \mathrm{~Hz},-\left\langle-\mathrm{NO}_{2}\right)\right.$.

Resibufogenin 3-Suberoyl-L-arginine Hydrochloride (IIc)_—A solution of IIb (50 mg) in pyridine (2 ml) was treated with an aq. solution of $\mathrm{L}$-arginine. $\mathrm{HCl}(10 \mathrm{mg}$ in $1 \mathrm{ml})$ in the manner as described in Ic. The crude product was chromatographed on silica gel $(600 \mathrm{mg})$. Elution with AcOEt-MeOH $(4: 1)$ and recrystallization of the eluate from MeOH-AcOEt gave IIc $(15 \mathrm{mg})$ as colorless amorphous substance. mp 123-125 ${ }^{\circ} . \quad[\alpha]_{\mathrm{D}}^{17}+25.0^{\circ}(c=0.08, \mathrm{MeOH})$. Anal. Calcd. for $\mathrm{C}_{38} \mathrm{H}_{56} \mathrm{O}_{8} \mathrm{~N}_{4} \cdot \mathrm{HCl} \cdot \mathrm{H}_{2} \mathrm{O}: \mathrm{C}, 60.74 ; \mathrm{H}, 7.92$; $\mathrm{N}, 7.46$. Found: C, $60.44 ; \mathrm{H}, 7.98 ; \mathrm{N}, 7.36$.

Digitoxigenin 3-Suberoyl-L-arginyl-L-arginine Diacetate (Id)_-A solution of Ib $(40 \mathrm{mg})$ in pyridine (2 $\mathrm{ml})$ was treated with an aq. solution of L-arginyl-L-arginine $\left.\cdot 2 \mathrm{AcOH}^{14}\right)(40 \mathrm{mg}$ in $0.5 \mathrm{ml})$ in the manner as described in Ic. The crude product obtained was chromatographed on silica gel $(500 \mathrm{mg})$. Effluent with $\mathrm{MeOH}-\mathrm{AcOH}-\mathrm{H}_{2} \mathrm{O}(3: 1: 1)$ was concentrated in vacuo below $40^{\circ}$, and the residue obtained was submitted to gel filtration on Sephadex $\mathrm{LH}-20$ using $\mathrm{MeOH}$ as eluent. After evaporation of solvent trituration of the eluate with $\mathrm{MeOH}$-ether gave Id $(10 \mathrm{mg})$ as colorless amorphous substance. $\mathrm{mp}$ 167-174 ${ }^{\circ}$ (decomp.).

13) All melting points were taken on a micro hot-stage apparatus and are uncorrected. Infrared (IR) and UV spectral measurements were run on JASCO Model IR-S and Hitachi EPS-3 spectrometers, respectively. NMR spectra were obtained on Hitachi Model R-20A spectrometer at $60 \mathrm{MHz}$; the chemical shifts are quoted as $\mathrm{ppm}$ downfield from tetramethylsilane used as an internal standard. Abbreviation used $\mathrm{s}=$ singlet, $\mathrm{d}=$ doublet, $\mathrm{q}=$ quartet, and $\mathrm{m}=$ multiplet. For preparative thin-layer chromatography (TLC) Silica gel HF (E. Merck AG, Darmstadt) was used as adsorbent.

14) L. Zervas, T.T. Otani, M. Winitz, and J.P. Greenstein, J. Am. Chem. Soc. 81, 2878 (1959). 
$[\alpha]_{\mathrm{D}}^{17}+10.2^{\circ}(c=0.10, \mathrm{MeOH}) . \quad$ Anal. Calcd. for $\mathrm{C}_{43} \mathrm{H}_{70} \mathrm{O}_{9} \mathrm{~N}_{8} \cdot 2 \mathrm{AcOH} \cdot 2 \mathrm{H}_{2} \mathrm{O}: \mathrm{C}, 56.49 ; \mathrm{H}, 8.27 ; \mathrm{N}, 11.22$. Found: $\mathrm{C}, 56.35 ; \mathrm{H}, 7.79 ; \mathrm{N}, 11.70$. NMR $\left(5 \%\right.$ solution in $\left.\mathrm{CD}_{3} \mathrm{OD}\right) \delta: 0.85\left(3 \mathrm{H}, \mathrm{s}, 18-\mathrm{CH}_{3}\right), 0.97(3 \mathrm{H}, \mathrm{s}, 19-$ $\left.\mathrm{CH}_{3}\right), 5.00\left(3 \mathrm{H}, \mathrm{m}, 3 \alpha-\mathrm{H}, 21-\mathrm{CH}_{2}\right), 5.90(1 \mathrm{H}, \mathrm{m}, 22-\mathrm{H})$.

Digitoxigenin 3-Suberoyl-L-arginyl-L-proline Acetate $(\mathrm{Ie})-A$ solution of $\mathrm{Ib}(93 \mathrm{mg})$ in pyridine $(10 \mathrm{ml})$ was treated with an aq. solution of L-arginyl-L-proline. $\left.\mathrm{AcOH}^{15}\right)(60 \mathrm{mg}$ in $5 \mathrm{ml})$ in the manner as described in Ic. The crude product obtained was chromatographed on silica gel (500 mg). Eluate with AcOEt-MeOH (1: 1) was further purified by gel filtration on Sephadex LH-20 using $\mathrm{MeOH}$ as eluent. After evaporation of solvent trituration of the eluate with hexane gave $\mathrm{Ie}(68 \mathrm{mg})$ as colorless amorphous substance. $\mathrm{mp} 184-$ $190^{\circ} .[\alpha]_{\mathrm{D}}^{17}-27.3^{\circ}(c=0.18, \mathrm{MeOH})$. Anal. Calcd: for $\mathrm{C}_{42} \mathrm{H}_{65} \mathrm{O}_{9} \mathrm{~N}_{5} \cdot \mathrm{AcOH}: \mathrm{C}, 62.61 ; \mathrm{H}, 8.24 ; \mathrm{N}, 8.30$. Found: $\mathrm{C}, 62.27 ; \mathrm{H}, 8.14 ; \mathrm{N}, 8.72$. NMR $\left(12 \%\right.$ solution in $\left.\mathrm{CD}_{3} \mathrm{OD}\right) \delta: 0.88\left(3 \mathrm{H}, \mathrm{s}, 18-\mathrm{CH}_{3}\right), 0.96(3 \mathrm{H}, \mathrm{s}, 19-$

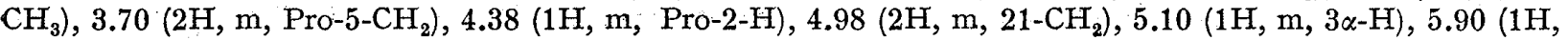
$\mathrm{m}, 22-\mathrm{H})$.

Transformation of Id into Pyrimidine Derivative (Ig)-A solution of Id (60 $\mathrm{mg})$ in acetylacetone$\mathrm{KHCO}_{3}(5.5 \mathrm{ml})$ was allowed to stand at $37^{\circ}$ for $78 \mathrm{hr}$. The resulting solution was extracted with $\mathrm{CHCl}_{3}$ and the extract was then methylated with $\mathrm{CH}_{2} \mathrm{~N}_{2}$ in the manner as described in If. The crude product obtained was submitted to the preparative TLC using AcOEt-MeOH $(20: 1)$ as developing solvent. The adsorbent corresponding to the spot $(R f 0.10)$ was eluted with AcOEt-MeOH $(10: 1)$, and recrystallization of the eluate from $\mathrm{MeOH}$-ether gave $\mathrm{Ig}(20 \mathrm{mg})$ as colorless prisms. mp 142-143 ${ }^{\circ} . \quad[\alpha]_{\mathrm{D}}^{16}+20.8^{\circ}(c=0.12$, $\mathrm{CHCl}_{3}$ ). Anal. Calcd. for $\mathrm{C}_{54} \mathrm{H}_{80} \mathrm{O}_{9} \mathrm{~N}_{8}: \mathrm{C}, 65.83 ; \mathrm{H}, 8.19 ; \mathrm{N}, 11.37$. Found: $\mathrm{C}, 65.31 ; \mathrm{H}, 8.28 ; \mathrm{N}, 10.98$. UV $\lambda_{\max }^{\mathrm{Meor}} \mathrm{nm}: 241,304$. NMR ( $4 \%$ solution in $\left.\mathrm{CDCl}_{3}\right) \delta: 0.85\left(3 \mathrm{H}, \mathrm{s}, 18-\mathrm{CH}_{3}\right), 0.95\left(3 \mathrm{H}, \mathrm{s}, 19-\mathrm{CH}_{3}\right), 2.28$ $\left(12 \mathrm{H}, \mathrm{s}\right.$, pyrimidine- $\left.4,6,4^{\prime}, 6^{\prime}-\mathrm{CH}_{3}\right), 3.70\left(3 \mathrm{H}, \mathrm{s},-\mathrm{COOCH}_{3}\right), 4.50(1 \mathrm{H}, \mathrm{m},-\mathrm{NH}$-pyrimidine $), 4.90(2 \mathrm{H}, \mathrm{m}$, $\left.21-\mathrm{CH}_{2}\right), 5.05(1 \mathrm{H}, \mathrm{m}, 3 \alpha-\mathrm{H}), 5.50(1 \mathrm{H}, \mathrm{m},-\mathrm{NH}$-pyrimidine $), 5.85(1 \mathrm{H}, \mathrm{m}, 22-\mathrm{H}), 6.28\left(2 \mathrm{H}, \mathrm{s}\right.$, pyrimidine-5, $5^{\prime}-$ $\mathrm{H}), 6.60(1 \mathrm{H}, \mathrm{m},-\mathrm{CONH}-), 7.10(1 \mathrm{H}, \mathrm{m},-\mathrm{CONH}-)$.

Transformation of Ie into Pyrimidine Derivative (Ih)- - A solution of $\mathrm{Ie}(42 \mathrm{mg})$ in acetylacetone- $\mathrm{KHCO}_{3}$ $(2 \mathrm{ml})$ was allowed to stand at $37^{\circ}$ for $72 \mathrm{hr}$. The resulting solution was extracted with $\mathrm{CHCl}_{3}$ and the extract was then methylated with $\mathrm{CH}_{2} \mathrm{~N}_{2}$ in the manner as described in If. The crude product obtained was submitted to the preparative TLC using AcOEt as developing solvent. The adsorbent corresponding to the spot ( $R f 0.10$ ) was eluted with AcOEt and the eluate was submitted to gel filtration on Sephadex LH-20 using $\mathrm{MeOH}$ as eluent. After evaporation of solvent trituration of the eluate with hexane gave $\mathrm{Ih}(17 \mathrm{mg})$ as colorless amorphous substance. $\mathrm{mp} 80-85^{\circ}$. $\quad[\alpha]_{\mathrm{D}}^{1 \mathrm{~B}}-21.0^{\circ}\left(c=0.10, \mathrm{CHCl}_{3}\right)$. Anal. Calcd. for $\mathrm{C}_{48} \mathrm{H}_{71} \mathrm{O}_{9} \mathrm{~N}_{5}$ : $\mathrm{C}, 66.87 ; \mathrm{H}, 8.30 ; \mathrm{N}, 8.12$. Found: $\mathrm{C}, 66.40 ; \mathrm{H}, 8.25 ; \mathrm{N}, 8.02$. UV $\lambda_{\max }^{\mathrm{MeoH}} \mathrm{nm}: 236.5,304$. NMR $(8.5 \%$ solution in $\left.\mathrm{CDCl}_{3}\right) \delta: 0.88\left(3 \mathrm{H}, \mathrm{s}, 18-\mathrm{CH}_{3}\right), 0.96\left(3 \mathrm{H}, \mathrm{s}, 19-\mathrm{CH}_{3}\right), 2.30\left(6 \mathrm{H}, \mathrm{s}\right.$, pyrimidine-4.6- $\left.\mathrm{CH}_{3}\right), 3.50(2 \mathrm{H}$, $\mathrm{m}$, Pro-5- $\left.\mathrm{CH}_{2}\right), 3.69\left(3 \mathrm{H}, \mathrm{s},-\mathrm{COOCH}_{3}\right), 4.50(2 \mathrm{H}, \mathrm{m}$, Pro-2-H, $-\mathrm{NH}$-pyrimidine $), 4.90\left(2 \mathrm{H}, \mathrm{m}, 21-\mathrm{CH}_{2}\right), 5.09$ $(1 \mathrm{H}, \mathrm{m}, 3 \alpha-\mathrm{H}), 5.89(1 \mathrm{H}, \mathrm{m}, 22-\mathrm{H}), 6.20(1 \mathrm{H}, \mathrm{m},-\mathrm{CONH}-), 6.30(1 \mathrm{H}, \mathrm{s}$, pyrimidine- $5-\mathrm{H})$.

Acknowledgement The authors are indebted to all the staffs of the central analytical laboratory of this Institute for elemental analyses and spectral measurements. This work was supported in part by a Grant-in-Aid for Scientific Research from the Ministry of Education, which is gratefully acknowledged.

15) P.M. Scopes, K.B. Walshaw, M. Wel ord, and G.T. Young, J. Chem. Soc., 1965, 782 